Прегледни чланак

doi:10.5937/zrpfns52-17547

Milena S Milošević, Ph.D. Student

University of Niš

Faculty of Law Niš

adv.mmilena@gmail.com

\title{
MATERIAL CONDITIONS FOR ESTABLISHING ADOPTION
}

Abstract: In this essay we dealt with regulation of material conditions for establishing adoption, divided into three groups: those that refer to the adoptee, those that refer to adopters and those mutually obligatory. We applied comparative analysis, thus making the adoption rules of European countries included, aside from our own. We analyzed the solutions proposed in the Pre-draft of the Serbian Civil Code, from the perspective of numerous benefits that are gained by adoption. We concluded that the domestic regulations that define material conditions for establishing adoption mostly consist of satisfying the needs of modern society, but that certain improvements in the sphere of conditions regarding the adopter are necessary.

Keywords: adoption, adopter, adoptee, child, parents.

\section{INTRODUCTION}

Adoption (lat. adoptio) represents a family law institution which establishes parental and other relations between two persons - adopter and an adoptee, via a legal act, therefore, artificially. It represents an ancient legal institution, facts of which have been changing throughout history. In the modern law, adoption represents an extremely humane institution, whose primary goal is protection of children without the guardianship by biological parents, but also gives a role of a parent to those who are unable to create progeny. Considering the fact that family relations similar to those which are based on the fact of birth are created between adopters and adoptees and their relatives, conditions for establishing adoption are numerous and pre-determined by imperative regulations. These can firstly be separated into material and formal. Material conditions are the minimal demands that must exist on the adopter's and adoptee's side so as to make adoption a legal act. 
Besides, adoption will only be rendered legally complete if the completion of material conditions has been confirmed by a statutory authority, via a strictly regulated procedure. Some of the material conditions must be fulfilled by the adopter, others must exist on the adoptee's side, and third ones must be met by both parties.

In this essay we researched various approaches to meeting material conditions for establishing adoption. We have compared rules of domestic law to those of the most significant or those European countries closest to us, pointing out their advantages and disadvantages. We gave special attention to solutions proposed in the Pre-draft of the future Civil Code of the Republic of Serbia ${ }^{1}$, assessing to what extent they contribute to the development of the institution of adoption. We displayed examples of court practice at particular spots, emphasizing conclusions from the most significant decisions of the European Court of Human Rights.

\section{CONDITIONS FOR ESTABLISHING ADOPTION ON THE ADOPTEE'S SIDE}

In positive Serbian law, complete adoption ${ }^{2}$, as the only type regulated by law, may be established only if it is an adoptee - a child ${ }^{3}$, and if there is an interest for his/her adoption, evaluated, generally, as well as via an estimate of whether the regulatory conditions regarding family-law status of the child are met and if an interested party is in consent about adoption. Therefore, only a minor ${ }^{4}$ may be

${ }^{1}$ Further down: Pre-draft, text available on the site www.mpravde.gov.rs/files/NACRT.pdf, access: 01.04.2018.

2 There were two distinct kinds of adoption in the age of Justinian: adoptio plena complete adoption and adoptio minus plena - the incomplete adoption. Complete adoption had a complete integration into a family as a result (whether an illegitimate child or an adoptive grand child), along with a break up of ties to the previous family. An incomplete adoption did not lead to the break up in those ties, thus making adoptee's rights to the adopter and his kin weaker (Tanja Kitanović, Marija Ignjatović, „Evolucija ustanove usvojenja od rimskog do svaremenog prava“, Zbornik radova Pravnog fakulteta u Novom Sadu (Zbornik radova PFNS) 4/2013, 165-168)). The same division exists in modern law. Complete adoption is equal as blood relation, and by its founding, relations between the adopter and his relatives and the adoptee and his descendants are established. Incomplete adoption does not lead to break up with ties to the previous family, making rights and obligations weaker and fewer when compared to a complete adoption. Following this line of thought, the adopter and his kin, by basic rule, may not inherit an adoptee, because the adoptee is being inherited by his/her blood relatives (Jelena Vidić, „Uticaj adoptivnog srodstva na zakonska nasledna prava", Zbornik radova PFNS 3/2006, 383).

${ }^{3}$ According to the Convention on the Rights of the Child (article 1), every human being that has not reached eighteen years of age is considered a child, unless the adulthood is reached earlier in the law by which the child is governed. (Convention text available on the site: www. unicef.org/serbia/Konvencijaipravimadeteta, access: 12.08.2017.).

${ }^{4}$ Nonage as one of the conditions by the adoptee is a logical consequence of the fact that adults, by definition, can take care of themselves, their rights and obligations, so they do not need 
adopted, after it has reached an age of three months ${ }^{5}$, under the condition that he/ she has not achieved complete contractual capacity, whose biological parents died or can not parent the child because they have been stripped of parental rights or contractual capacity ${ }^{6}{ }^{7}$ A child whose parents are unknown or can not be found

protection given by complete adoption. In the Pre-draft a possibility of adopting an adult was proposed, if there were particularly justified reasons for it, evaluated by the minister in charge of family protection (an Alternative from the article 2323). In Montenegrian law, complete adoption is only possible if the person in question is a child younger than ten (article 131 of the Family Code of the Republic of Montenegro (Porodični zakon Crne Gore, „Službeni list Crne Gore”, br. 1/200, further referred to as FC RM, available on the site: www.sudovi.me/podaci/osul/informacije/ info_doc/836.pdf, access: 29.06.2018.). An adoptee may be a child younger than eighteen when dealing with incomplete adoption, and must consent to the adoption if older than ten (article 133 FC RM). In French law, a child younger than fifteen may be adopted, provided that he/she spends six months with possible adopters. An exception exists in this case, when a child has been adopted prior to turning fifteen, and other conditions for adoption were not met, unlike the present moment. Same exception exists in the case that the adoptee was younger than fifteen, because later a complete adoption may be established, as long as an adoptee is a minor or up until after two years of reaching adulthood (article 345 section 2 Code Civil, further referred to as CC, available on the site: www.legifrance.gouv.fr/content/download/1950/13681/version/3/.../Code_22.pdf, access: 29.06.2018). With regular adoption, however, no age limitations by the adoptee are stipulated (article 360 section $1 \mathrm{CC})$.

${ }^{5}$ A period of three months from the relevant event is needed for adoption of a child of unknown parents in Montenegrian and Croatian law (article 124 section 3 FC RM and article 181 section 2 of the Family Code of the Republic Croatia (Obiteljski zakon, „Narodne novine“, br.. 103/15, hence referred to as FC RC, available on site: www.zakon.hr/z/88/Obiteljski-zakon, access: 29.06.2018.) The lower age limit is regulated with the interest of the adoptee and his parents in mind, mother firstly, who may make an ill-conceived decision consenting to the adoption, under stress induced by the act of deliverance (Tanja Kitanović, „Institut usvojenja u novom porodičnom zakonodavstvu Srbije", Novine u porodičnom zakonodavstvu, Niš 2006, 133, Slobodan Panov, Porodično pravo, Beograd 2010, 257, Zoran Ponjavić, Porodično pravo, Kragujevac 2007, 214). The rule about the minimum age is in accordance with the rules of parents giving consent in the process of adoption, because that may not be done before a child becomes of the age of two months, while the given consent may be withdrawn, and only once, within a timeframe of thirty days (article 95 section 4 of the Family Code of the Republic of Serbia, (Porodični zakon, „Sl. glasnik RS”, br. $18 / 2005,72 / 2011-2$. zakon i 6/2015, hence referred to as FC RS, available on site $w w w$.paragraf. rs/propisi/porodicni_zakon.html, access: 29.06.2018.).

${ }^{6}$ Ponjavić remarks that the interests of the parents are jeopardized, because both deprivation of parental rights and contractual capacity are temporary (Z. Ponjavić, 215). There is danger to the interests of the adopters as well, because it is possible that the biological parents may disturb them. Consent of the adoptee should be, however, taken into consideration, due to which it may be expected that the fact that the child's parents are alive and known would not interfere with their relationship with the adopters.

${ }^{7}$ The interest of underage parents to remove the danger of their child getting adopted is protected by the rules of gaining contractual capacity before adulthood. Regulations from the article 11 section 2 and 3 FC RS stipulate that contractual capacity is gained by marriage before adulthood with the permission of the court, while an underage person who is over sixteen and has become a parent and reached physical and mental maturity required for independent care of one's own personality, rights and interests, court may allow the status of full contractual capacity. 
because their residence is unknown may also be adopted. If there are none of the aforementioned obstacles to conduct parental rights, a child can still be adopted, in the case of his/her parents gave consent to establishing adoption. ${ }^{8}$ All mentioned conditions are collectively labeled as general suitability of the adoptee. ${ }^{9}$ In any case, establishing adoption must be in the best interest of the child - adoptee. ${ }^{10}$

From the perspective of the adopter, the most agreeable condition is adoption of a child whose biological parents have died or are unknown, or their residency is unknown, because the likelihood that the biological parents will at some point interfere with the relationship between the adoptee and the adopter is, in the first scenario - nonexistent, and in the second one - quite slim.

Parents must consent to adoption, or the guardian must. Consent may be given with or without marking out the adopter. Even in the latter case, we are talking about a unilateral and explicit abandonment of a child, not about a contract with future adopters. ${ }^{11}$ As stated in the previous paragraphs, a parent may not consent to adoption before the child reaches the age of two months. Given consent may be withdrawn, but only once, within thirty days. ${ }^{12}$ If the parent is complete-

\section{${ }^{8}$ See article 91 FC RS. \\ ${ }^{9}$ See Gordana Kovaček Stanić, Porodično pravo, Novi Sad 2005, 368.}

${ }^{10}$ See article 89 FC RS. Kitanović questions the context of this legal standard, emphasizing that it might be criteria that contributes the preservation of the child's identity, national, ethnic, racial or religious belonging of the adoptee and the adopters, or his/her biological parents ( $\mathrm{T}$. Kitanović, 135). For example, Ponjavić considers that objecting adoption by the grandparents via a dead parent, may also be of significance in the process of adoption, exactly in the context of the best interest rule application (Z. Ponjavić, 216). We consider that keeping the child's best interest in mind during the process of establishing adoption should be considered an obligation of all of the participants in the process, mostly that of the organ upon which the adoption is decided, that in every specific case all of the circumstances are carefully considered and rated, thus making the decision of adoption based on an all-inclusive analysis of the factual state, not only on fulfillment of objective legal conditions. Moreover, we represent two examples from the practice of European court of human rights. In the case of Pontes v. Portugal (Chamber Judgement) the court has established that the applicants' rights of a private and family life were twice violated, because they were cut off from their child, which was later adopted. Even though we are talking about applicants who were relieved of their child due to drug abuse and regardless of the fact that it has nicely accepted it's adopters, according to the ruling of the European court, the established adoption was not in the child's best interest. Namely, the applicants enrolled in a rehab program, got employed, and the right of the parents and, before all else, the child, is to live together. A similar standpoint regarding the right of a child to live with its mother and maintain contact with her has been taken by the European court of human rights in the case Zhou v. Italy (Judgement). It was found that establishing complete adoption is not in the child's best interest, but a life with the mother or an open adoption rather is, with suitable support of social protection services. See aforementioned verdicts on the web site hudoc.echr.coe.int, access: 01.04.2018.

${ }^{11}$ Z. Ponjavić, 216.

${ }^{12}$ See article 91 and article 95 FC RS. In Russian law, parents' consent may be withdrawn until the conclusion of the adoption process, that is, up until the competent court's decision (article 129 section 2 Семейный кодекс Россиской Федераиии, hence referred to as FC RF, available on 
ly deprived of contractual capacity or parental rights, or the right to make decisions that impact a child's life, his consent to establish adoption will not be warranted. ${ }^{13}$ The statement in which consent is given is a personal statement of will, which must be provided in writing, freely and seriously, or it may be rendered null and void. Consent of the adoptee is another point of adoption being legally binding. If the child has reached the age of ten and is capable of deduction, his/her opinion regarding adoption must be taken into consideration. ${ }^{14}$ This kind of solution is in accordance with the tendency of modern law to enable a child to express free will whenever possible. In Croatian law, consent to establish adoption must be given by a child who has reached twelve years of age ${ }^{15}$, and thirteen in the French law ${ }^{16}$. As aforementioned, Family Code of RM regulates that consent to (incomplete) adoption must be given by a child older than ten. ${ }^{17}$ According to the rules of BGB, required age is fourteen. When the nationality differs from the nationality of the adopter, consent from the family court must be acquired, unless the specific case

site: www.semkod.ru, access: 29.06.2018). According to the family law of Montenegro and Croatia, parents may withdraw consent within thirty days (article 139 FC RM and article 188 section 6 FC RC). However, the cases in which the Croatian law is applied to, general consent may be given when the child is six weeks old (article 194 section 3 FC RC). Consideration timeframe deadline in German law is eight weeks from the day of birth. If the child was entrusted to its mother's care, the father may consent to adoption even before the birth ( $§ 1747$ section 2 and 3 Bürgerliches Gesetzbuch, hence referred to as BGB, available on site: www.gesetze-im-internet.delenglisch_bgb/ englisch_bgb.pdf, access: 29.06.2018.). In French law, consent may be withdrawn within two months. If the child is already entrusted to someone, the decision about the continuance of adoption will be made by the court, keeping the child's best interest in mind (see article 248-3 CC). The parents may consent to adoption of a child younger than two, only in the case of adoptee and the adopter being blood related or in-laws up to the sixth degree of kinship, or the child is entrusted to the service of child aid or an institution for adoption (article 348-5 CC).

${ }^{13}$ See article 96 FC RS. Russian law differs from Serbian in such a manner that it regulates that consent will not be asked from a parent who does not live with the child for unjustified reasons and neglects the parental duties for a period longer than six months (article $130 \mathrm{FC} \mathrm{RF}$ ). In Montenegrian law, consent of the parents deprived of contractual capacity or parental rights is not required, but neither that of the one not living with the child for unjustified reasons, with an extra condition that in the period of three months has mostly neglected parental duties. Consent is not needed by a parent whose residence has been unknown for a period of six months, during which the child was neglected (article 129 FC RM). In French law, the opinion of a parent who shows no interest in a child to a point that shows that the child's health and morale are in danger will not be taken into consideration, thus rendering the ability of parental rights abuse possible (article 348-6 $\mathrm{CC}$ ). In German law, a parent who is permanently unable to give any statement or is of unknown residence will not be asked for consent ( 1747 section 2, 3, 4 BGB). In the event of rigid neglect of parental duties (permanent or particularly serious), family court consent will be necessary instead (§ $1747 \mathrm{BGB})$.

${ }^{14}$ See article 98 FC RS.

${ }^{15}$ See article 191 section 1 FC RC.

${ }^{16}$ See article 345 section 3 and article 360 section 3 CC.

${ }^{17}$ See article 131 and 133 section 2 FC RM. 
is under the jurisdiction of German law. Still, the will of the adoptee has a stronger note for the outcome of the procedure of adoption. ${ }^{18}$ Family code of RF gives that consent of the adoptee shall be deemed necessary, if the child has reached the age of ten, unless the child has lived with adopters that he/she considers to be his/her parents prior to the request being filed. ${ }^{19}$

In comparative law, a few more conditions may be found regarding passive adoptive capacity. For instance, Family code of RF gives that a written consent of the foster parents, that is, those in charge of the mentioned institution for adoption is required when the situation is about an adoptee currently being fostered or is institutionalized in some form of medical or social care. More attention to a child's interest has been given, therefore adoption will be allowed without the aforementioned consent, if this aligns with the adoptee's interests..$^{20}$ An additional assumption of passive adoptive capacity in German law is the absence of conflict of interest between an adoptee (and his/her descendants, if the person is of legal age) and the biological children of the adopter ${ }^{21}$, and it may be considered as one of the elements of the "in the child's best interest" standard. When a person who is married is in the position of the adopter, the spouse must also give consent, considering the fact that he/she is able to provide it. ${ }^{22}$ The final rule is the same as the one from French Civil Code. ${ }^{23}$ In Croatian and Montenegrian law it is strictly regulated that the child of underage parents may be adopted, only explicitly if by the time a child turns one year old it becomes clear that the child will not be fostered by family or relatives of the parents. ${ }^{24}$

\section{CONDITIONS ON THE ADOPTER'S SIDE}

Family code of RS strictly regulates general assumptions of active adoptive capacity, which consider personal properties, marital status and citizenship of the adopter. It is deemed necessary that the future adopters attend a preparatory course for adoption which is conducted through a special program. Overall, lawful term for all mentioned conditions is general suitability of the adopter. ${ }^{25}$

\footnotetext{
${ }^{18}$ See $\S 1746$ section 1 BGB.

${ }^{19}$ See article 132 FC RF.

${ }^{20}$ See article 131 FC RF.

${ }^{21}$ See $\S \S 1745$ and 1769 BGB.

${ }^{22}$ See $\S 1749$ section 2 BGB.

${ }^{23}$ See article 343-1 CC.

${ }^{24}$ See article 183 section 2 FC RC and article 124 FC RM.

${ }^{25}$ Aside from general, a special suitability for adoption is required so that the adopters and the child suit each other's needs, which purports an evaluation by the guardianship organ.
} 


\subsection{Personal properties and marital status of the adopter}

A family that will not differ from a normal, functional family created by birth should be a product of complete adoption, thus making personal properties which include conscientiousness of the adopters necessary, and would imply that parental rights over the adoptee would be executed in accordance with his/her best interest. It is therefore regulated that general suitability for adoption should not go to a person that has been fully or partially deprived of parental rights, because he/she can not be expected to act in adoptee's best interest, if he/she has not treated his/her child in such a manner. Same goes for a person who is partially or fully deprived of contractual capacity, because he/she is in no condition to take care of $\mathrm{him} /$ herself, let alone adoptee. A person suffering from a disease that may cause harm to the adoptee and a person convicted for any felony against marriage and family, sexual freedom and against life and body, will also be deprived of adoptive rights. ${ }^{26}$ In the first case we are talking about a person who is unable to take care of the child due to physical or mental problems, and in the second case about a person who was proven not to respect family values, and will abuse his/her adoptive rights. ${ }^{27}$

A child may be adopted by spouses or members of an extra-marital community. The goal is to form a complete family through adoption, as well as an ideal of modern society and law. ${ }^{28}$ Adoption by a single person is still possible in two cases. Firstly, a child of one's spouse or extra-marital partner may be adopted, and secondly, a minister in charge of family protection may find that there are particularly good reasons for a child to be adopted by a person living alone. ${ }^{29}$ For example,

${ }^{26}$ See article 100 FC RS.

${ }^{27}$ In FC RM (article 127 section 2), it is emphasized that right to adoption isn't that of the person whose spouse or an extra-marital partner has reached the necessary conditions, which is a consequence of the possibility that an incomplete adoption may be established with a single adopter.

${ }^{28}$ The Pre-draft contains a rule when an incomplete adoption is established, the status of an adopter may be achieved by only one of the spouses or extra-marital partners (article 2334 section 3$)$.

${ }^{29}$ See article 101 section 2 and 3 FC RS. European Court of Human Rights has spoken about the right of a single person to adopt solely. In the verdict (Chamber judgement) Gözüm v. Turkey the court has determined that the applicant's right to a private and family life was violated (article 8 of the European Convention on Human Rights), because she was unable to have her personal name enlisted in the part of the form about the mother of the adopted child in his personal documents, because there was a legal void in the Turkish law when a single adopter is adopting. The right of a single adopter to adopt is protected by the verdict (Chamber judgement) J. M.W.L $v$ Luxemburg. The court has taken the stance that the existance of a legal void for single adoption is not a sufficient enough reason not to acknowledge the validity of the Peruan court verdict to give the adoption to an applicant living alone. The court had valued the already existing family ties between the applicant and the adoptee, a generally accepted rule about single adoption, and the fact that the Peruan court decisions about establishing complete adoption had already been acknowledged and executed in Luxemburg, even those referring to single adopters. See mentioned verdicts on the web site hudoc.echr.coe.int, access: 01.04.2018. 
establishing adoption may be possible when a person has already taken care of a child, and no other suitable adopters can be found - spouses or extra-marital community members. ${ }^{30}$ In Montenegrian law, complete adoption is only possible when spouses or extra-marital partners adopt together, or a biological child of one of the spouses or a member of the extra-marital community is to be adopted. ${ }^{31} \mathrm{~A}$ child may be adopted by a single person as aforementioned, only with consent of his/her spouse or extra-marital partner when dealing with a partial adoption. Adopter can also be a person living alone, considering there are reasons to establishing adoption. ${ }^{32}$ According to the regulations of the FC RS, right to complete adoption, as regulated by law, may be established with no difference whatsoever to adopters who are married or are members of an extra-marital community. ${ }^{33}$ German Civil Code stipulates that spouses may adopt a child together, unless one of the spouses adopts a child of the other or one of the spouses doesn't have the authority to make contracts or has not reached twenty one years of age. The decision of the family court may replace the statement of consent to the adoption of the other spouse in rare cases when a spouse is eligible as an adopter. The condition is that the intended adoption is in no conflict with family interests, or those of the other spouse. ${ }^{34}$ A person who is not married may adopt a child independently. ${ }^{35}$ The peculiarity of Russian law is reflected in the fact that a child may be adopted by a single spouse, but with consent of the other one, unless they live separately for a period longer than one year and uncertainty in regards to the adopter's spouse's residency. ${ }^{36}$

\subsection{Citizenship, attendance in preparatory programs and other conditions by the adopter}

Entrusting a child onto parental guardianship to a different person represents a delicate matter, that must be addressed with outmost responsibility, therefore, having additional protection of a child in mind, special conditions for a foreign citizen wishing to be an adopter are in place. He/she may only adopt a child that has been registered in the Unique adoption registry ${ }^{37}$ longer than a year, since no suitable adopters of Serbian citizenship could have been found. A minister in charge of family protection must consent to this adoption, and also give permission to

\footnotetext{
${ }^{30}$ Gordana Kovaček Stanić, 317.

${ }^{31}$ See article 132 FC RM.

${ }^{32}$ See article 134 FC RM.

${ }^{33}$ See article 185 FC RC.

${ }^{34}$ See $\S 1741$ section 2 BGB and $\S 1749$ BGB.

${ }^{35}$ See 1741 section 2 BGB.

${ }^{36}$ See article 133 FC RF.

${ }^{37}$ It is about an unique record of persons with active and passive adoptive capacity on the territory of the Republic of Serbia, lead by the ministry in charge of family protection.
} 
adoption before the time frame regulated by law, if he/she deems that course of action to be in the best interest of a child. ${ }^{38}$

A complex, multi-dimensional process as adoption is, adopters must be adaptable, ready for what lies ahead. Program of their preparation is given by the minister in charge of family protection and must be attended by all future adopters, except those who adopt the child of their spouse or an extra-marital partner. ${ }^{39} \mathrm{It}$ is conducted by an organ of guardianship in accordance with the future residence, that is, the future residence of the adopters. ${ }^{40}$

Specific conditions by the adopter exist in Russian law. A law exists for a case when siblings are being adopted, they must be adopted by the same person. Exceptions are allowed only in the case that they are in the best interest of the adoptee. ${ }^{41}$ Range of persons that are deprived of adoptive rights is very broad. A child may not be adopted by persons partially/completely deprived of contractual capacity; spouses, if one of them is partially or completely incapable to contract; persons deprived of parental rights (fully or partially); persons that were discharged of parental duties due to unfulfilling the regulations; persons who lost the adopter status for reasons that they are guilty of; persons suffering from any disease from the list of the Government of RF and which disables them from taking care of a child; persons who don't have sufficient income to support a child; persons without permanent residency; persons convicted of willing acts against lives and health of other men, and lastly, persons whose residences are not up to sanitary and technical codes. Conditions related to income and residence may be disregarded if it is in the best interest of the adoptee. They certainly do not apply to the step mother and step father of the adoptee. ${ }^{42}$ Persons who are not married may not adopt a child together. ${ }^{43}$ If multiply

${ }^{38}$ See article 103 FC RS and G. Kovaček Stanić, 372-373. In the Pre-draft it was specified that a foreign citizen may adopt a child of Serbian nationality, if no adopters or fosters could have been found among the domestic citizens, that is, only when a child can not be provided any other suitable form of care in our country. An compendious solution was alternatively suggested by which the only conditions for this type of adoption is the fact that no adopters of domestic nature can be found and that the minister in charge is on board with the adoption (article 2336). We find the former suggestion, as more restrictive, more appropriate to the interests of domestic adoptees. Foreign adoption is also exclusively allowed in Croatian and Montenegrian law, only if it is of exquisite interest to the child and with approval of the minister in charge (see article 125 FC RM and article 186 FC RC). In Russian law, a foreigner or an appatrid may adopt a child if the adopters of domestic nationality, or the ones with permanent residence in RF, can not be found in the period longer than six months since the child was put on the federal adoptee database, but also in the case of child's kin (see article 124 section 4 FC RF).

${ }^{39}$ See article 102 FC RS.

${ }^{40}$ See article 11 of Rulebook about the adoption preparatory program (Pravilnik o programu pripreme za usvojenje,,,Sl. glasnik $R S^{\prime}$, br. 18/05), available on site www.zavodsz.gov.rs/PDF/ podzak/7. Pravilnik\%20o\%20programu\%20pripreme\%20za\%20usvojenje. pdf, access: 05.04.2018.

${ }^{41}$ See article 124 section 3 FC RF.

${ }^{42}$ See article 127 section 1 FC RF.

${ }^{43}$ See article 127 section 2 FC RF. 
parties are interested in adopting a single child, priority will be given to his/her relatives. ${ }^{44}$

\subsection{Adopter structure in the Republic of Serbia}

According to republic data provided by the Ministry of Labor, Employment and Veteran and Social Affairs for the period between 2006-2017. there were a total of one thousand four hundred and forty two adoptions, one hundred and seventy two of which were international. The most foreign adopters came from Sweden and the USA (see chart 1). In this entire timeframe there were only four individuals who adopted a child (see chart 2). In the Unique adoption registry there are seven hundred and forty three adopters. There are two hundred and sixty four children at some stage of the adoption process. General suitability has been acknowledged with two hundred and forty adoptees, while thirty four children were assigned to adaptation with potential adopters.

Republic average of established adoptions is one hundred and twenty eight per year. The international part in the total number of adoptions in the past twelve years is $11,15 \%$. Swedish part is $4,99 \%$, while the American part being somewhat smaller, only $3,63 \%$. For comparison, Canadians that are present on this list are on third place, with total of $0,58 \%$. We were surprised by the small number of adoptions by the members of neighboring countries. They make a total of $0,26 \%$ of foreign adoptions, even though geographical, cultural, language and other barriers were minimal. It is our opinion that the main cause of this is of economic nature, that is, that the life standard in these countries is low, and they have a large number of abandoned children, and generally, those prone to adoption.

\begin{tabular}{|c|c|c|c|}
\hline Year & Total adoptions & Domestic adoptions & International adoptions \\
\hline 2006. & 97 & 88 & 9 \\
\hline 2007. & 138 & 126 & 12 \\
\hline 2008. & 149 & 137 & 12 \\
\hline 2009. & 134 & 119 & 15 \\
\hline 2010. & 106 & 92 & 14 \\
\hline 2011. & 101 & 89 & 12 \\
\hline 2012. & 110 & 102 & 8 \\
\hline 2013. & 155 & 142 & 13 \\
\hline 2014. & 195 & 174 & 21 \\
\hline 2015. & 156 & 138 & 18 \\
\hline 2016. & 128 & 108 & 20 \\
\hline 2017. & 73 & 55 & 18 \\
\hline
\end{tabular}

Chart 1

${ }^{44}$ See article 127 section 3 FC RF. 


\begin{tabular}{|l|c|c|c|c|c|c|c|c|c|c|c|c|c|}
\hline Country & 2006. & 2007. & 2008 & 2009 & 2010. & 2011. & 2012. & 2013. & 2014. & 2015. & 2016. & 2017. & Укупно \\
\hline Sweden & 3 & 5 & 2 & 1 & 4 & 3 & 4 & 6 & 12 & 14 & 15 & 8 & 77 \\
\hline USA & 4 & 3 & 8 & 7 & 8 & 6 & 1 & 6 & 4 & 3 & 3 & 3 & 56 \\
\hline Canada & & 1 & 1 & 1 & & 2 & & 1 & 1 & 1 & & 1 & 9 \\
\hline Spain & & 1 & & & & & & & & & & 5 & 6 \\
\hline Slovenia & & & 1 & & & & 2 & & & & & & 3 \\
\hline France & & & & 2 & 1 & & & & & & & & 3 \\
\hline Switzerland & 2 & & & & & & & & & & & & 2 \\
\hline Luxemburg & & 2 & & & & & & & & & & & 2 \\
\hline Great Britain & & & & 2 & & & & & & & & & 2 \\
\hline Spain-Serbia & & & & & & & & & 2 & & & & 2 \\
\hline $\begin{array}{l}\text { Portugal - } \\
\text { Germany }\end{array}$ & & & & & & & & & 1 & & 1 & & 2 \\
\hline Izrael & & & & & & & & & & & 1 & 1 & 2 \\
\hline Kazakhstan & & & & 1 & & & & & & & & & 1 \\
\hline Italy & & & & 1 & & & & & & & & & 1 \\
\hline Ireland & & & & & 1 & & & & & & & & 1 \\
\hline Croatia & & & & & & 1 & & & & & & & 1 \\
\hline Greece & & & & & & & 1 & & & & & & 1 \\
\hline $\begin{array}{l}\text { Sweden - } \\
\text { Greece }\end{array}$ & & & & & & & & 1 & & & & 1 \\
\hline
\end{tabular}

Chart 2

\section{MUTUAL CONDITIONS FOR ESTABLISHING ADOPTION}

So that the adoption could be based lawfully, certain negatively determined conditions must be met. This is about the facts of kin and guardianship, that represent impediments for establishing adoption, so they must not exist in the relationship between the adoptee and the adopter. On the other hand, there needs to be a certain age difference between them, so their relationship would reflect that of a parent - child even further.

\subsection{Kinship and guardianship as an adoptive impediments}

Family Code of RS stipulates that establishing adoption between blood relatives in a straight line is impossible and a diagonal line between siblings and step siblings. ${ }^{45}$ Adoption creates family relations, which would culminate without FC RM.

${ }^{45}$ See article 92 FC RS. As well as: article 182 section 1 FC RC and article 123 section 2 
prior limitations. ${ }^{46}$ Guardian, moreover, may not adopt his/her ward. ${ }^{47}$ This is due to the fact that guardianship and adoption are two different forms of protection of children who do not have parental advisory. This problem is of temporary character, and the guardian who wishes to adopt his/her ward may cause the termination of guardianship, and initiate the process of adoption. ${ }^{48}$ Pre-established adoption also represents an adoptive impediment, so the child may only be re-adopted by a spouse or an extra-marital partner of the adopter. ${ }^{49}$ This condition comes from the parental relationship between the adopter and an adoptee, which is exclusive by nature. Kitanović reasonably points out a situation when adopters are deprived of parental rights, with the goal of proving that the previous rule is, still, disputable. ${ }^{50}$ In French law, it is allowed to establish new adoption if the adopter has passed away, as well as when a spouse of the deceased is in the role of the adopter, or a new partner of the spouse of the deceased. ${ }^{51}$ French Civil Code enables establishing ordinary adoption over an adoptee from complete adoption, if there are severe reasons to do so. ${ }^{52}$ German Civil Code ( $(1742)$ stipulates that during the lifetime of the adopter, the only other person eligible is his/her spouse. In Swedish Family law, adoption of previous adoptee is allowed, but must be approved by the primary adopters who in this case possess the ground of biological parents. ${ }^{53}$

\subsection{Age difference between the adoptee and the adopter as an assumption of adoption}

In domestic family law, the position of adoptive parent may regularly be achieved by a person eighteen to sixty three years old, bearing in mind that adoptee can be a child of age between three months and eighteen years, while the age difference between the adopter and adoptee must be at least eighteen and at most forty five years. ${ }^{54}$ This is not an absolute rule, because the minister in charge of family protection may allow adoption by a person who is less than eighteen years older than the adoptee, or older than forty five, but only if it is in the best interest of the

\footnotetext{
${ }^{46}$ Huseinspahic considers this interference a result of "in the child's best interest" criteria. (Ajdin Huseinspahić, „Usvojenje u službi najboljeg interesa deteta”, Zbornik radova Pravnog fakulteta ,Džemal Bijedič”, Mostar 2/2014, 204).

47 See article 94 FC RS. As well as article 182 section 2 FC RC and article 123 section 3 FC RM.

48 G. Kovaček Stanić, 373.

${ }^{49}$ See article 93 FC RS as well as G. Kovaček Stanić, 370.

${ }^{50}$ T. Kitanović, (2006), 134.

${ }^{51}$ See article 346 CC.

${ }^{52}$ See article $360 \mathrm{CC}$.

${ }^{53}$ Ana Čović, „Usvojenje u pravu Švedske”, Evropsko zakonodavstvo 49/50, Beograd 2014, 394.

${ }^{54}$ See article 99 FC RS.
} 
child-adoptee. ${ }^{55}$ Age difference of over forty five years should not be an obstacle when a child of one's own spouse is in question. ${ }^{56}$ Alleged age limitations are, by the way, regulated by the common age in which partners decide to become parents.

A solution has been proposed in the Pre-draft, without the upper age limit of the adopter. ${ }^{57}$ In Montenegrian law, age limits of the adopter are regulated differently, so the person wishing to adopt must be at least thirty years old and fifty at most, but in such a way, so that the difference between them and the adoptee is never less than eighteen. These conditions must be met by at least one of the adopters, when there are two. If siblings are being adopted simultaneously, these conditions must be met with at least one child. ${ }^{58} \mathrm{~A}$ person older than fifty may adopt, with the condition that he/she is not older by the same number of years from the adoptee and only with approval of a minister in charge of social care ${ }^{59}$ According to the regulations of Croatian law, a child may be adopted by a person who is at least twenty one years old, if he/she is eighteen years older than the adoptee. The status of an adopter may exclusively be given to a younger person, but in no case whatsoever may the adopter be older than the adoptee less than eighteen years ${ }^{60}$. We consider the solution from the Russian law to be adequate, in which the only condition related to age is the difference of at least sixteen years, which can be, with court approval, lesser than that. ${ }^{60}$ A general regulation of the German law makes sense, and it says that the adopter must be twenty five years of age. ${ }^{61}$ However, persons who adopt children of their spouses are privileged, as well as one of the spouses from the pair that adopts a child mutually, because in these cases an adopter can be twenty one. ${ }^{62}$ French law has a particular condition that says that the adopters may be spouses, at least two years married or older than

${ }^{55}$ See article 99 FC RS. Considering the fact that the adopter must be able to work, so that he may take care of the child's interests as a parent, we conclude that establishing adoption could be exclusively be allowed to an emancipated minor, making the age difference between the adoptee and the adopter no less than sixteen years (As well as: Z. Ponjavić, 217-218).

${ }^{56}$ S. Panov, 248, Z. Ponjavić, 220.

57 See article 2332 of the Pre-draft.

${ }^{58}$ In Croatian law, this rule applies to successive adoption of siblings (see article 126 FC RC).

${ }^{59}$ See article 126 FC RM. We think that age differences are more appropriate in Serbian law, because they fit the natural and social norms more adequately. Namely, in domestic law, adopter may be at least eighteen years old and at most sixty two, with the difference between the adoptee and the adopter never to be less than eighteen or bigger than forty five. The Montenegrian law solution in which a person younger than thirty may not adopt we consider to be illogical, especially if the adoptee is under ten years old, and the adopter at least twenty eight, because the minimum difference will certainly be the required eighteen years. On the other hand, we consider that adopting a person seventeen years of age by a person of thirty is generally justified as much as the adoption of a child less than a year old by a person of fifty.

${ }^{60}$ See article 184 FC RC. We don't find even this solution the best, because we see no reason why a person of eighteen should not be allowed to adopt a one year old or a two year old child.

${ }^{61}$ See article 128 section 1 FC RF.

${ }^{62}$ See 1743 BGB. 
twenty eight. ${ }^{63}$ The age difference between the adopter and the adoptee must regularly be at least fifteen years, ten if a child of the spouse is being adopted. If the reasons are sufficient, the court will allow adoption, even though the previous condition has not been met. ${ }^{64}$ The French legislator has clearly bore in mind that maturity is necessary to enjoy parental rights. The legislator has also taken into consideration the most common natural age difference between a parent and a child. In the end it was up to the court to prevent the rigidity of regulations and norms from harming the best interest of the adoptee, so that it may detach from them in a satisfactory manner.

\section{CONCLUSION}

Adoption falls under those institutions of family law that have always enjoyed a high level of various theorists' attention, given how its functions are numerous and multidimensional. It merits a special level of attention in the present time, because it is noticeable that certain changes are taking place in family law, going along with contemporary needs of the modern society.

In this essay we have researched material conditions for establishing adoption, because it is the field in which the most advances may be achieved in the process of adoption rules development. We have analyzed three groups of regulations - those referring to the adoptee, those referring to the adopter, and, lastly, those mutually binding. As we have dealt with both domestic and foreign rules of comparative law, we have concluded that those solutions that affect the adoptee directly are the most similar. In every legislator's center of attention was obviously the interest of the adoptee, with the spirit of actual legal order or legally-technical reasons leading to certain nuances while actualizing certain norms. We single out the family status and citizenship out of all conditions relating to adopters. We emphasize, however, that the solution in which spouses and extra-marital partners adopt children together is logical and in no way degrading. Domestic children should be adopted by foreigners and apatrids only in special cases. We justify this point of view with the best interest of the adoptee and it should secure protection in a complete family, whenever possible, as well as certain guarantees that the adoptee will enjoy all the rights regulated by domestic law. To this end we support the proposed bill change in the Pre-draft, in the part where international adoption is only possible when no domestic adopters or guardians could have been found, nor could the child have been taken care of in any other way without parental guardianship. We also support the discontinuation of maximum age difference

\footnotetext{
${ }^{63}$ See article 343-1 CC.

${ }^{64}$ See article 344 CC.
} 
between the adoptee and the adopter, keeping in mind the statistical data that indicate that the majority of the adopters are in their fifth, or even sixth decade of their lives, whilst respecting the fact that an ever bigger age difference is occurring between children and their biological parents. We have commended the Russian law regulation that stipulates that the only condition is for there to be at least sixteen years of age difference especially. According to this we quote the stance of Kovaček Stanić:,,Revised European Convention on adoption determines the age of the adopter as a condition, not only as a minimum age. It is expected that the minimum age of the adopter should not be less than eighteen or greater than thirty years, with maximum age not being determined. The convention proclaims that there should be a certain age difference, keeping in mind the best interest of the child, the best being at least sixteen years (article 9). These kinds of solutions enable adoption for persons older than regulated, up to no limit, but under the condition that that adoption is in accordance with the child's best interest." ${ }^{\prime 65}$

The fact imposing as the final conclusion is the fact that domestic adoption rules are more than satisfactory, but certain legislative interventions are welcome, so that they may protect the interest of all parties even better, with the priority being given to the child - adoptee. This will extort extra efforts and commitment of all kinds of resources, but the institutions of adoption, by which the most humane goals are being achieved, deserves it most vividly.

${ }^{65}$ G. Kovaček Stanić, 374. 


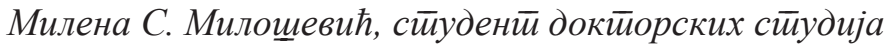
Универзитетеи у Нищу

Правни факулиетей у Нищу

adv.mmilena@gmail.com

\section{Материјални услови за заснивање усвојења}

Сажсейак: У овом раду смо се бавили уређењем майеријалних услова за заснивање усвојења, йодељених у йри грруиее: на оне који се односе на усвојеника, оне који обавезују усвојитееље и оне које морају исиинииии и једни и друг̄и. Примењивали смо уйоредну анализу, йа су нащим истираживањем, иоред домаћих, била обухваћена и ирравила о усвојењу йојединих евройских земаља. Анализовали смо и рещења ирредложена у Преднаирйу будућег Грађанског̄ законика Рейублике Србије са стиановищйа бројних ииљева који се устиановом усвојења остиварују. Закључили смо да домаћа ирравила којима су йройисани майеријални услови за заснивање усвојења уг̄лавном йог̄одују задовољавану извесних ӣотиреба савременог̄ друшиива, али и да су неойходна незнайна йобољщаға у сфери услова који се йичу усвојитељьа.

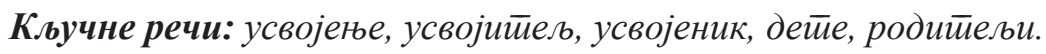

Датум пријема рада: 21.05.2018. 